\title{
Morpho-anatomical structure and DNA barcode of Sonchus arvensis $\mathbf{L}$.
}

\author{
DWI KUSUMA WAHYUNI ${ }^{1, \bullet}$, SHILFIANA RAHAYU ${ }^{2}$, PUTUT RAKHMAD PURNAMA ${ }^{1}$, \\ TRIONO BAGUS SAPUTRO ${ }^{3}$, SUHARYANTO ${ }^{4}$, NASTITI WIJAYANTI ${ }^{4}$, HERY PURNOBASUKI $^{1}$ \\ ${ }^{1}$ Department of Biology, Faculty of Science and Technology, Universitas Airlangga. Kampus C, Jl. Mulyorejo, Surabaya 60115, East Java, Indonesia. \\ Tel.: +62-31-5936501, 5924617, Fax.: +62-31-5936502, `email: kusumaanwar@yahoo.com \\ ${ }^{2}$ Department of Biology, Faculty of Science and Technology, Universitas Islam Negeri Sunan Kalijaga. Jl. Adi Sucipto, Sleman 55281, Yogyakarta, \\ Indonesia \\ ${ }^{3}$ Department of Biology, Faculty of Science, Institut Teknologi Sepuluh Nopember. Jl. ITS, Surabaya 60111, East Java, Indonesia \\ ${ }^{4}$ Faculty of Biology, Universita Gadjah Mada. Jl.Teknika Selatan, Sekip Utara, Bulaksumur, Sleman 55281, Yogyakarta, Indonesia
}

Manuscript received: 8 July 2019. Revision accepted: 31 July 2019.

\begin{abstract}
Wahyuni DK, Rahayu S, Purnama PR, Saputro TB, Suharyanto, Wijayanti N, Purnobasuki H. 2019. Morpho-anatomical structure and DNA barcode of Sonchus arvensis L. Biodiversitas 20: 2417-2426. Tempuyung or show thistle (Sonchus arvensis L.) belongs to the Asteraceae. Morpho-anatomy and DNA (Deoxyribonucleic Acid) barcoding of the plant correlates with species identification and metabolite synthesis. This research aims to look at morpho-anatomical structures and analyze the DNA barcode of Sonchus arvensis L (tempuyung). Three samples used for morpho-anatomical analysis are leaves, stems, roots, fruit, and seeds. Anatomical samples are made using the embedding method. DNA barcode uses multiple locus from plastid genome: $r b c L$ and $m a t K$. Morpho-anatomical structure of tempuyung showed a similar structure of Sonchus genus. The stem presents in the intercellular space, whereas the roots and leaves present in the vascular tissue and the seeds. Fruits present in each part of the body. Tissues that formed root are epidermis, cortex, endoderm, and stele. Tissues that formed stem are epidermis, cortex, and stele. Tissues that formed leaf are epidermis, cortex, phloem, and xylem. Tissues that formed the fruit and seed are paranormal and sclerenchyma tissues. Sonchus arvensis sequence for $r b c L$ has a similar $100 \%$ maximum identity to $r b c L$ gene of $S$. arvensis, Sonchus asper, and Sonchus oleraceus, whereas Sonchus arvensis mat $K$ sequence has a similar $99.31 \%$ maximum identity to other $S$. arvensis matK sequences in BLAST system. These findings provide morpho-anatomical features and DNA barcoding for identification of $S$. arvensis. from others species in the same genus. Thus also can be considered as pharmaceutical standard.
\end{abstract}

Keywords: Anatomy, DNA barcoding, matK, morphology, Sonchus arvensis, rbcL, tempuyung

\section{INTRODUCTION}

Indonesia has many potentials of medicinal plants that have not been studied, at least 9,600 species of plants have medicinal properties. One of them is Sonchus arvensis L., which is found throughout Indonesia and known as an invasive plant. The local name of $S$. arvensis in Indonesia is tempuyung. Tempuyung belongs to the Asteraceae family and is known to have many benefits for treating asthma, bronchitis, cough, and has antibacterial, antiinflammatory, antioxidant, diuretic, sedative, and hypnotic activity (Delyan 2016). Most of S. arvensis metabolites are contained in the leaves. It has chemical compounds such as flavonoids (kaempferol, luteolin-7-glucoside, and apigenin7-O-glucoside), coumarin, and taraxasterol (Sriningsih et al. 2012). Sulaksana et al. (2004) and Delyan (2016) also reported that tempuyung leaf contains high flavonoid and triterpenoids.

Species genus Sonchus is distinguished among themselves by a life form, lamina shape, stem character, number of flowers in inflorescences and color, number of edges on the achenes, achenes size and color, and so on (Svitlana et al. 2018). Mejias et al. (2012) reported that Sonchus could differ by the size of flowers, stamens size, and morphology of chromosomes. Qureshi et al. (2008) reported that Sonchus genus could differ by pollen analysis, whereas anatomical analysis of genus Sonchus has not been reported.

According to Sukandar and Safitri (2016), the use of tempuyung as medicine is safe even for pregnant women without side effects. Secondary metabolite compounds are located explicitly in particular part of the plant so that it may differ in cells, tissues, or organs of a plant. Secondary metabolite compounds in a plant can be detected by screening the plant extracts. Besides screening, an anatomical analysis is also crucial in determining the distribution of metabolite compounds in cells or tissues within each plant organ.

In addition to morpho-anatomical studies, it is also essential to do a molecular study for identification species. Previous research from Qureshi et al. (2008) also reported about pollen morpho-anatomical studies in Sonchus genus to find different and similar characters, but in vegetative organs not done. Species identification method living thing has developed from morphological identification to molecular identification based on short DNA pieces that are called "DNA barcode" (Hebert et al. 2013). DNA barcode has applicative functions for example for the ecological survey (Dick and Kress 2009), identification taxon-taxon cryptic (Lahaye et al. 2008), and confirmation of plant samples medicines (Xue and Li 2011). Consortium for Barcode of Life (CBOL) recommends the use of two 
plastid genes, for examples $r b c L$ and $m a t K$ as barcodes standards (Hollongsworth et al. 2009).

Genes from the plastid genome are uniparentally inherited non-recombining, and an inherently stable genome (Kress et al. 2005). Current results designate that at least two plastid genes, better a multi-locus code, are required to specify a consistent plant DNA barcode, those are combination gene like $r b c L$, mat $K$ and internal spacer such as trnH-psbA (Lucas et al. 2012). RbcL is commonly used in phylogenetic analysis and can be simply to amplify; the sequence can also align in nearly all terrestrial plants. Thus $r b c L$ is one of the right DNA barcoding regions for plants at the family and genus levels (Li et al. 2004).

So far, study about the molecular indicator of Sonchus $s p$ has been widely conducted by using various marker such as ISSR (Psaroudaki et al. 2015; Subositi and Mujahid 2019), RAPD (Elkamali et al. 2010; Doğan et al. 2018), multiple-locus barcode matK-ITS (Kim et al. 2007; Mejías et al. 2018) moreover complete plastid genome (Cho et al. 2019; Kim et al. 2019). However, still, limited data provide molecular marker, primarily for $S$. arvensis using $r b c L$ and mat $K$ locus.

Morpho-anatomy structures and DNA barcodes affect the biological systems of the plant, including the synthesizing process of secondary metabolites, so morphoanatomical characters and DNA barcodes contribute the pharmaceutical standard. Because of Sonchus genus has several plant types so that it is vital to know the morphoanatomical characters and DNA barcodes to prevent misusing plants. This study aims to describe morphoanatomical characters and to analyze DNA barcodes $($ rbcL+matK) of Sonchus arvensis $\mathrm{L}$.

\section{MATERIALS AND METHODS}

\section{Plant materials}

The material used is the tempuyung plant (Sonchus arvensis L.) which has been grown in Medicinal Plant Garden "Taman Husada Graha Family", Surabaya, Indonesia and determined in Purwodadi Botanic Gardens, Indonesian Institute of Sciences, Pasuruan, Indonesia.

\section{Morpho-anatomical characterization}

The component observed in the morphological study is a description of tempuyung's whole organs. The study was conducted on three different individual plants. The components observed in morphological studies are root, stem, leaves, flower, and fruit. The anatomical character studies are the cells contained in the tissue, secretion cells; tissue contains in the organs (root, stem, leaf, fruit, and seed). Sample preparation is using paraffin embedding with fixation, dehydration, dealcoholizing, infiltration, blocking in pure paraffin, slicing, gluing, staining, and closing (Sutikno 1989). The morpho-anatomical character was analyzed descriptively.

\section{DNA extraction and quantification}

Genomic DNA was isolated from $80 \mathrm{mg}$ of fresh leaves of $S$. arvensis. The isolation was conducted using the Plant
DNA Genomic Kit (Tiangen, China) according to the manufacturer's protocol. The quality and integrity of isolated DNA were checked by $1 \%$ gel electrophoresis (Promega, USA) and subjected to UV transilluminator.

\section{PCR amplification and sequencing}

Analysis of polymerase chain reaction (PCR) was carried out using two different primer pair. Both primers $R b c L$ (Forward: 5'AAGTTCCTCCACCGAACTGTAG 3'; Reverse: 5'TACTGCGGGTACATGCGAAG 3') and MatK (Forward: 5' TGGTTCAGGCTCTTCGCTATTG 3'; Reverse: 5'CTGATAAATCGGCCCAAATCGC 3') were specific designed for Asteraceae family using Primer3 (Rozen and Skaletsky 2000). Selection conditions included: TM $\left(57-60^{\circ} \mathrm{C}\right)$ and $\mathrm{GC}$ content $(40-60 \%)$. A reaction $(35 \mu \mathrm{L})$ included $17.5 \mu \mathrm{L}$ GoTaq®Green Master Mix, each 350 to $500 \mathrm{nM}$ forward and reverse primers, $50 \mathrm{ng}^{-1}$ DNA template, and nuclease-free water until volume reached 35 $\mu \mathrm{L}$. Thermocycling condition included: $5 \mathrm{~min}$ hot start at $94^{\circ} \mathrm{C}, 35$ main cycles of $30 \mathrm{~s}$ at $94^{\circ} \mathrm{C}, 45 \mathrm{~s}$ at $56^{\circ} \mathrm{C}$, and 45 $\mathrm{s}$ at $72^{\circ} \mathrm{C}$. The reaction was completed with a final extension at $72^{\circ} \mathrm{C}$ for $5 \mathrm{~min}$. PCR reactions were performed in an Eppendorf® master cycler personal. The PCR amplification efficiency was verified by $1 \%$ agarose (Promega, USA) gel electrophoresis using 0.5X TBE buffer. After verification of the success of PCR amplification, the reaction volumes were scaled up to 50 $\mu \mathrm{L}$ for sequencing at Macrogen Inc. (Korea).

\section{Sequence and phylogenetic analysis}

DNA sequences obtained from $r b c L$ and matK were then analyzed using the rapid identification tool BLAST (Nucleotide BLAST: www.ncbi.nlm.nih.gov) to find regions of local similarity between sequences. The first five high similar sequences from each gene were aligned with ClustalW (Thompson et al. 1994) using BioEdit (Hall 1999). A cluster analysis was conducted using the distance method UPGMA (Unweighted Pair-Group Method with Arithmetic Mean). The output data were processed using MEGA 7 (Kumar et al. 2016) to build the phylogenetic trees.

\section{RESULTS AND DISCUSSION}

\section{Morphological characters}

Morpho-anatomical characters were analyzed descriptively. S. arvensis (Tempuyung) in Indonesia has a herbaceous habitus and erect, annual herb, but there is perrenial one in Pakistan (Qureshi et al. 2002). Tempuyung has a root rosette (Figure 1.A, B) and all the body has a white sap, this character can find in all member of the genus Sonchus. The sap can be found on the leaves, stems, and roots with various intensity. The root of the tempuyung is a taproot in yellowish-white color (Figure 1.C), long cone-shaped that grow downside and has a short root branch.

The stem is very short, herbaceous, round, and the nodus is clearly visible (Figure 1.D), green in color, has many trichomes and a monopodial bifocal. The trichomes 
on the stem are a unique character because in another member of genus Sonchus have not many trichome (Mejias et al. 2012). Height of tempuyung reaches $64 \mathrm{~cm}$ tall. It is different from $S$. oleraceus that have $1.5 \mathrm{~m}$ tall (Chauhan et al. 2015). Another character in the stem that remarkably differs in genus Sonchus is branching, (Mejias et al. 2012).

Tempuyung's leaves are simple (single lamina). It is considered as incomplete because it has no petiole and vagina; there are two shapes of the leaves, which are spear and lanceolate (Figure 1.E). All member in genus Sonchus have two kinds of leaves with various shaped depends on species and location (Qureshi et al. 2002). Leaves on the root rosette part hugging rods, spear-shaped, pointed apex, flat base, pinnate vein, lobulated leaves margin, sleek adaxial (upper surface) colored in dark green (Figure 1.E1), while the abaxial (lower surface) colored in light green and has trichoma (Figure 1.E2). Edge of leaves S. arvensis in Pakistan is serrated, but in Indonesia, it is not serrated (Qureshi et al. 2002). S. arvensis has soft-thin leaves flesh like $S$. oleraceus; it differs from $S$. asper that has thick leaves (Mejias et al. 2012)

In the generative phase, leaves shaped in lanceolate, arranged alternately on the inflorescence, pointed apex, wavy base, pinnate vein, flat-sharp margin, thin leaves flesh with the rough surface (has trichome), the upper surface is greener (Figure 1.E1) than the lower part (Figure 1.E2). Subositi et al. (2018) reported that seat leaves and the edge of the seat could differ species in Sonchus genus.

The flower of genus Sonchus is resembled in all member but differ in size. The flower of $S$. arvensis is a terminal flower (Figure 1.F), compound inflorescence, monoecious, multi symmetry, cymose corymb, has flower ribbon, ovule covered by a cup-shaped part of the flower. There is small bract in the pedicle, shown by the white arrow in Figure F. The sepals are green and have soft brownish fur (Figure 1.H). The petals are colored in bright yellow (Figure 1.H). The ovule is located deep in the receptacle of the flower. Tempuyung's long central pedicle has generative leaves. According to Subositi et al. (2018), pedicle characteristic can differ species in Sonchus genus. When the flowers are fertilized, the petal will fall and form the fruit and seed (Figure 1.I).
The reproduction of tempuyung is relatively quick and accessible through the seeds. Tempuyung's fruit is considered as pure, dry indehiscent one-seeded fruit with a hard wall, brownish, and oval-shaped with 5-12 indentations along the sides (Figure 1.J). Pappus or white hairs present in one of the fruit edges, while the other edge is attached to the base of the flower. These accessories allow the fruit to be easily propagated by the wind. Tempuyung's fruit is so hard that it will not break when the seeds germinate. Seeds are protected in hard wall fruit, and there is only one seed in each fruit. Tempuyung's seed is tiny and colored in brownish-white. The seed of Sonchus has a high level of germination; it is about $90 \%$. The seed can survive until one year in the soil surface. Light and salinity are not an absolute requirement in germination, because the germination more influenced by soil humidity. The size of the seed bank can be reduced by germination, insect predation, and decay (Chauhan et al. 2015).

\section{Anatomical characters}

Anatomical studies are critical to know the structure of the organ, the cells, and the tissues that are possible to synthesize secondary metabolite compounds (Sharma et al. 2017). Each organ has its characteristic, which indicates the location of secondary metabolites synthesis.

The cross-section structures of the basal side of tempuyung young root from the outside in are composed of epidermal, cortical, and pith tissue (xylem and phloem). Exodermis and endodermis are still not visible in the young root. The root epidermis is round, small, dense, and thickened walls (Figure 2.A1). The cortex is composed of several giant cells, and there are plenty of air spaces inside. The stele and cortex segments are separated by endodermis, radial transport system, and actynostele. The root base has a more differentiated transport system. In the root cap (Figure 2.A2), there is a small number of airspace; the cortical cells are composed of large, well-ordered cells. In the cortex, there are more dense-colored cells, indicating a secondary metabolite synthesis therein. Anatomical characters of the vegetative organ in genus Sonchus is similar so anatomical characteristic can be used to taxonomy studies (Kandemir et al. 2006).

Table 1. A morphological character among genus Sonchus

\begin{tabular}{|c|c|c|c|c|}
\hline Character & S. arvensis & S. oleraceus & S. asper & S. erzincanicus \\
\hline Habitus & herbaceous, $0,65-1,5 \mathrm{~m}$ & herbaceous, 0,3-1,25 m & herbaceous, 0,1-0,7 m & Herbaceous \\
\hline Stem & $\begin{array}{l}\text { erect, round, annual to } \\
\text { perennial }\end{array}$ & erect, round, annual & $\begin{array}{l}\text { erect, round, annual to } \\
\text { biennial }\end{array}$ & erect, round, perennial \\
\hline Leaf & $\begin{array}{l}\text { spear to the lanceolate, } \\
\text { margin of leaf serrated, } \\
\text { soft-thin leaves flesh }\end{array}$ & $\begin{array}{l}\text { Sagittarius, amount of } \\
\text { serration on leaf margin, } \\
\text { soft-thin leaves flesh }\end{array}$ & $\begin{array}{l}\text { Auriculatus, the margin of } \\
\text { leaf serrated and spiniest than } \\
\text { other, fleshy and thick }\end{array}$ & $\begin{array}{l}\text { oblong to the elliptic, } \\
\text { margin of leaf serrated, } \\
\text { spiny, fleshy and thick }\end{array}$ \\
\hline Root & Taproot, root rosette & Taproot, root rosette & Taproot, root rosette & Taproot, root rosette \\
\hline Flower & $\begin{array}{l}\text { yellow, compound } \\
\text { inflorescence, actinomorf }\end{array}$ & $\begin{array}{l}\text { yellow, compound } \\
\text { inflorescence, actinomorf }\end{array}$ & $\begin{array}{l}\text { yellow, compound } \\
\text { inflorescence, actinomorf }\end{array}$ & $\begin{array}{l}\text { yellow, compound } \\
\text { inflorescence, actinomorf }\end{array}$ \\
\hline Pollen & Spheroidal & Spheroidal, tricolporate & Spheroidal, tetracolporate & anomocytic \\
\hline $\begin{array}{l}\text { Fruit and } \\
\text { seed }\end{array}$ & Hard, brown, wrinkled & $\begin{array}{l}\text { Hard, brown, narrow, } \\
\text { wrinkled }\end{array}$ & Hard, brown, most wrinkled & Hard, brown, wrinkled \\
\hline Branching & Near inflorescence & Near inflorescence & From stem & Near inflorescence \\
\hline
\end{tabular}




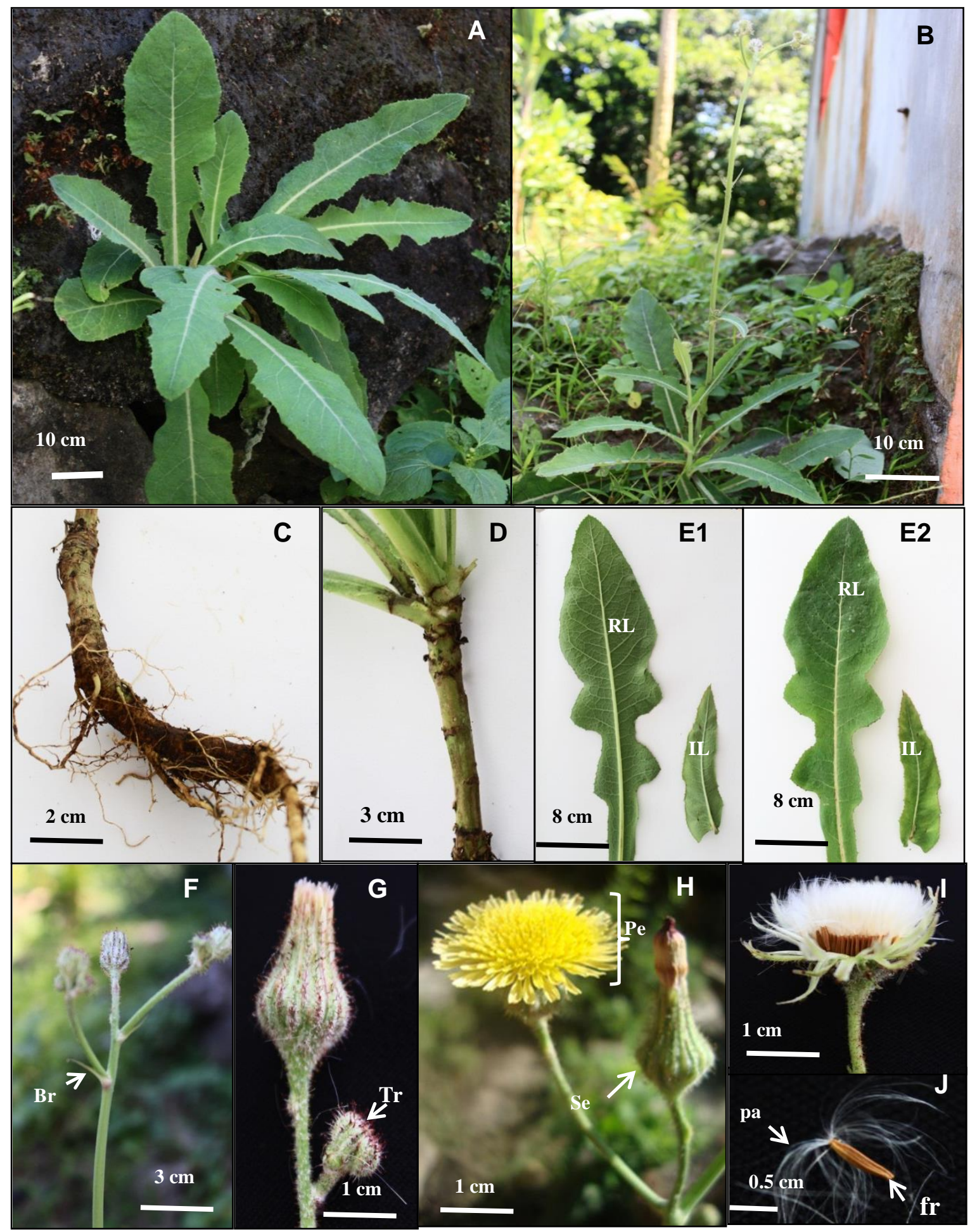

Figure 1. Sonchus arvensis L. morphology, A. Vegetative phase, B. Generative phase, C. Root, D. Shoot, E. Leaf; E1. Abaxial roset leaf (RL) and inflorescence leaf (IF), E2. Adaxial RL and IF, F. Bract (Br), G. Trichome on the flower (Tr), H. Petal (Pe) and Sepal (Se), I. Fruits arrangements in flower, J. Fruit (fr) and Pappus (pa)

Tempuyung's stem has a structure that is not much different from other Asteraceae plants too. The external anatomical arrangement of the stem is one layer of a flatshaped epidermis, a single-layered of collenchyma, irregular cortical cell shape, and more abundant than epidermal cells (Figure 2.B). The cortex consists of 7-9 layers, usually oval-shaped or rectangular. The cortex containing latex are seen transparently. The transport system is open collateral (xylem and phloem are limited by cambium tissue) and arranged circularly around the pith. The xylem trachea cells are plentiful, and wall thickened, while the phloem is located outside the xylem and is 
limited by the cambium tissue. Adult phloem cells do not have a cell nucleus, whereas, in young phloem, the cells are small and still have no cell lysis, thus resembling cambium and making it difficult to distinguish. Phloem sometime consists of amylum, its similar to other species in genus Sonchus like S. erzincanicus (Kandemir et al. 2006). Cambium cells are tiny and thin-walled, making it challenging to observe. The black arrows in Figure 2.B3 indicate the elongation of the transport system to the outer part of the cortex. This indicates the presence of leaf forming activity. In the deepest part, there is a pith that has a large-dense cell. There are many interstitial spaces in the cortex (Figure 2.B2) which have darker shades. Those may be the storages of secondary metabolite secretion.

The arrangement of leaf tissue from the outside consists of a flat, one-layered epidermis which has thickened cuticle. There are many trichomes on the surface, but they are not visible (Figure 2.C). Midrib has a triangle-shaped and has 1 or 2 layers collenchyma under the epidermis. In the midrib of the leaf (Figure 2.C1), there is a thick irregularly shaped cortex, an open collateral transport system, and an unclear cambium wall. Therefore it is difficult to observe. In the mesophyll tissue section, there are more densely colored cells. In the phloem, there is a more concentrated interstitial space. This indicates the presence of secondary metabolite storage in that section. Sclerenchyma cells in bundles are dense.

The lamina (Figure 2.C2) is composed of a larger epidermis compared to the midrib, beneath the epidermis is a mesophyll tissue composed of the thick palisade, and spongy tissue are not distinct. The spongy tissue is spaced apart. On the sample presented, the sponge tissue was lysis during the preparation, so that it is difficult to observe. There is much chlorophyll in the mesophyll. The vegetative organ in genus Sonchus is similar so that it will work hard to distinct species by anatomical characteristic (Subositi et al. 2018).

The anatomical arrangement of fruits and seeds of tempuyung is very distinctive. The tempuyung fruit is grooved and hard, while the seeds are inside (Figure 3.D1). In younger fruits, the seeds have not formed so that the seed chamber is empty. Tempuyung's fruit wall is thickened. Most of the forming tissues of tempuyung's fruit are deep parenchymal tissues, in which there is a starch granule (shown by black arrows in Figure 3.D2) and contains bioactive compounds. Also, there is a thickening of sclerenchyme in the grooves of the fruit, small sclerenchyma cells, compacted, and has a thick cell wall. Besides strengthening, sclerenchyme tissue also serves as a transport system on the fruit and seeds.

The middle layer is thickened with a cell structure that extends over the seeds of the starch layer (Figure 3.D2). The structure of the seed endosperm is very distinctive, composed of densely tight, small meristematic cells and many starch granules which indicates secondary metabolite compounds therein. The endosperm of the tempuyung plant is in two pieces, so it is considered as dicotyledons.

\section{DNA barcoding}

Both $r b c L$ and matK genes were successfully amplified in $S$. arvensis. These primers were specially designed to amplify both genes among the Asteraceae family.

Table 2. An anatomical character among Sonchus genus

\begin{tabular}{|c|c|c|c|}
\hline \multicolumn{2}{|c|}{ Character S. arvensis } & S. oleraceus & S. asper \\
\hline Root & 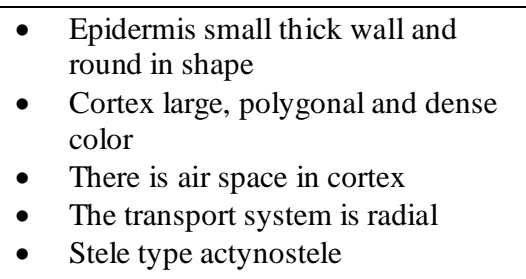 & 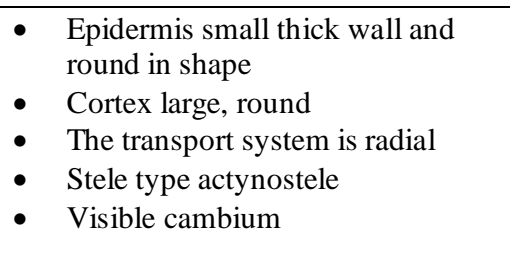 & 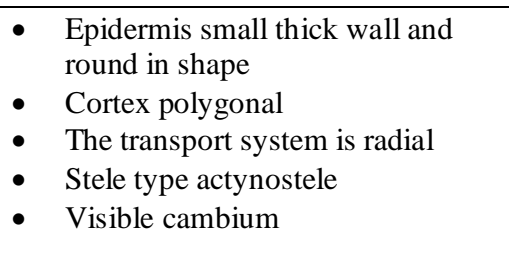 \\
\hline Stem & $\begin{array}{l}\text { - One layer epidermis, flat in shape. } \\
\text { - } \text { One layer collenchyma } \\
\text { - } \text { 7-9 layers cortex, irregular in shape } \\
\text { - } \text { collateral. } \\
\text { - Phloem consist of starch }\end{array}$ & $\begin{array}{l}\text { - } \quad \text { One layer epidermis, flat in shape. } \\
\text { - } 2-3 \text { layers collenchyma } \\
\text { - } \text { 6-7 layers cortex consist of latex } \\
\text { - The transport system is collateral. } \\
\text { - Phloem consist of starch } \\
\text { - Visible cambium }\end{array}$ & $\begin{array}{l}\text { - One layer epidermis, rectangular. } \\
\text { - } 2-3 \text { layers collenchyma } \\
\text { - 6-7 layers cortex consist of oxalate } \\
\text { crystals, polygonal in shape } \\
\text { - The transport system is collateral. } \\
\text { - Visible cambium }\end{array}$ \\
\hline Leaf & $\begin{array}{l}\text { One layer epidermis with thick } \\
\text { cuticula, and less trichoma, } \\
\text { rectangular. } \\
\text { - Palisade and sponge tissue are not } \\
\text { distinct. } \\
\text { - The transport system is open } \\
\text { collateral }\end{array}$ & $\begin{array}{l}\text { One layer epidermis with thick } \\
\text { cuticula, and many trichomas, } \\
\text { rectangular. } \\
\text { - Palisade and sponge tissue are not } \\
\text { distinct. } \\
\text { - The transport system is open } \\
\text { collateral }\end{array}$ & $\begin{array}{l}\text { One layer epidermis with thick } \\
\text { cuticula, and many trichomas, } \\
\text { rectangular. } \\
\text { - Palisade and sponge tissue are not } \\
\text { distinct. } \\
\text { - The transport system is open } \\
\text { collateral. } \\
\text { - Visible cambium. }\end{array}$ \\
\hline
\end{tabular}




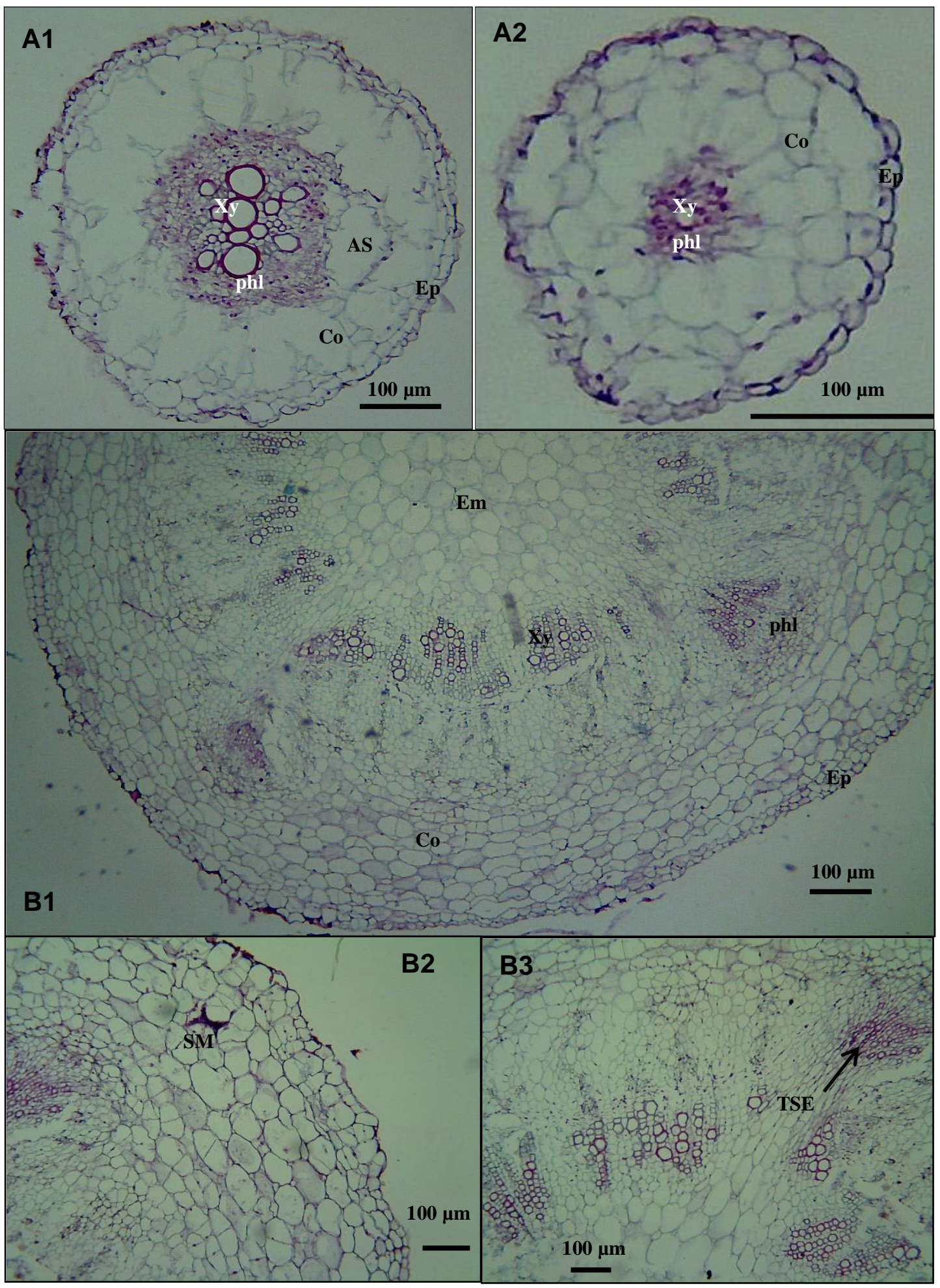

Figure 2. A Cross-section of roots, A1. Root base [Epidermis (Ep), Cortex (Co), Air space (AS), Phloem (Phl), Xylem (Xy)]. A2. Root cap [Epidermis (Ep), Cortex (Co), Phloem (Phl), Xylem (Xy)]. B. Cross-section of shoots, B1. Shoot layers [Epidermis (Ep), Cortex (Co), Air space (AS), Phloem (Phl), Xylem (Xy)], B2. Secondary metabolite accumulation (SM), B3. Transport system elongation (TSE)

The sequence length from $r b c L$ was $433 \mathrm{bp}$, and $m a t K$ was $288 \mathrm{bp}$, whereas GC contents were $42.7 \%$ and $35.4 \%$, respectively. The BLAST result (Table 3) for $r b c L$ barcode displayed that $S$. arvensis MN206020 (this study) for $r b c L$ has a similar $100 \%$ maximum identity to $r b c L$ gene of $S$. arvensis (JX848427.1), Sonchus oleraceus (KM360989.1),
S. oleraceus (EU385018.1), Sonchus asper (MF135322.1), S. asper (HM850372.1). Furthermore, close relationship to S. arvensis MN218598 (this study) for $m a t K$ sequence was shown in Table 4 which has a similar $99.31 \%$ maximum identity to other S. arvensis matK sequences (MH265200.1; MF770209.1; MG225099.1; MG225031.1; MG 225020.1). 
Nucleotide base differences are found in nucleotides number 32 and 33 from $S$. arvensis MN218598 sequence against other comparative sequences (Table 5). The $r b c L$ amplicon of $S$. arvensis MN206020 seems in the conserved region of Sonchus genera. It can be seen in BLAST result which indicated only one sequence intraspecies $(S$. arvensis JX848427.1) and others were from inter-species ( $S$. oleraceus KM360989.1, S. oleraceus EU385018.1, S. asper MF135322.1, S. asper HM850372.1). This result can be caused the $r b c L$ sequences to evolve slowly, and this locus has the faintest divergence of plastid genes in Angiospermae (Kress et al. 2005) considerably. Hence, it is not suitable at the species level due to its scanty discriminatory ability (Fazekas et al. 2008; Lahaye et al. 2008). Even though $r b c L$ by itself can not make the favored feature of a barcoding locus. It is possible that $r b c L$ in combination with diverse plastid or nuclear loci can make precise identification (Chase et al. 2007; Kress and Erickson 2007).

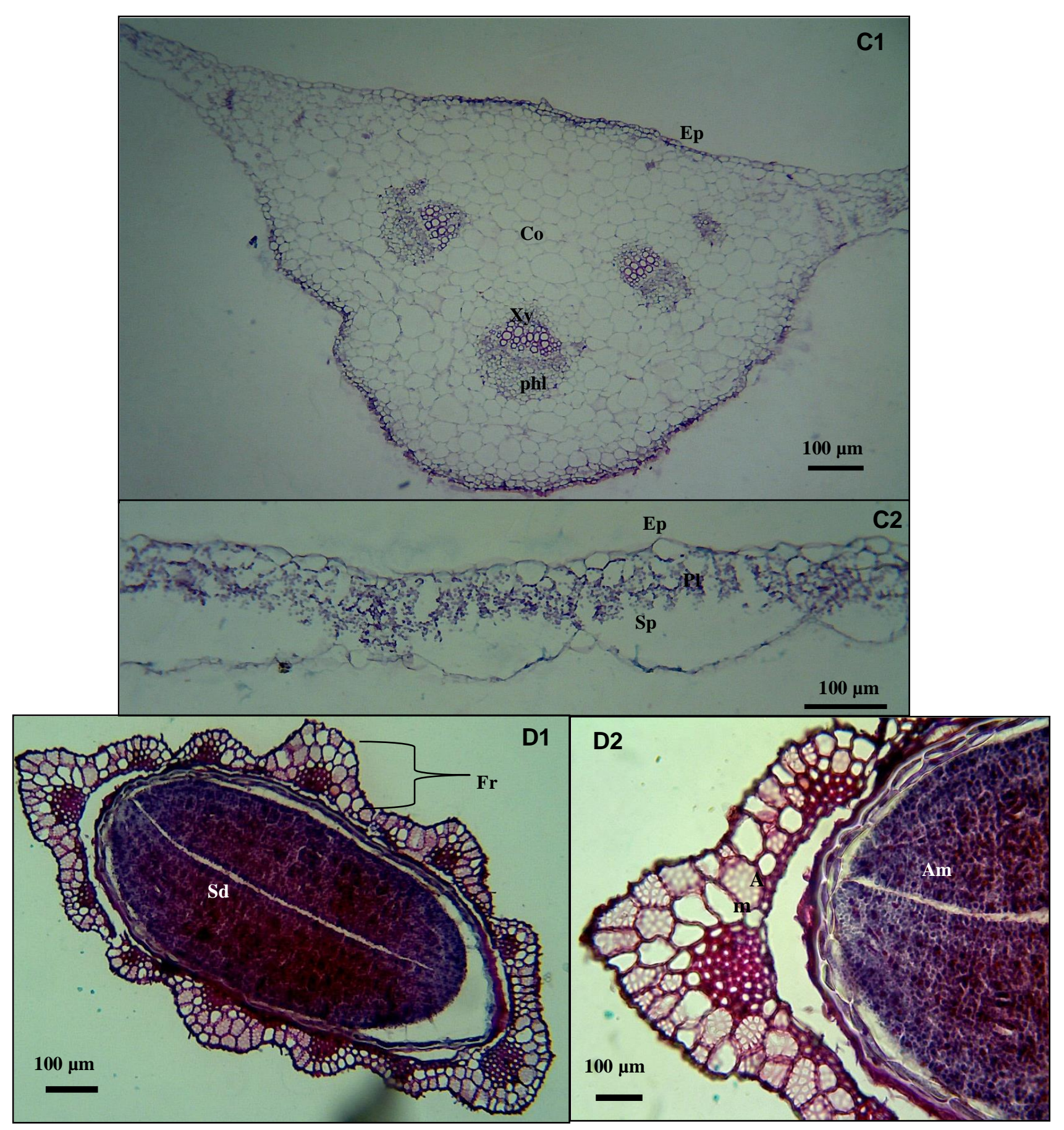

Figure 3. C. Cross-section of a leaf, C1. The midrib of the leaf; Ep: epidermis, Co: Cortex, phl: phloem, Xy: xylem, C2. Lamina of leaf; Ep: epidermis, P1: palisade, Sp: Sponge. D1. Cross-section of fruits (Fr) and seed (Sd), D2. Amylum (Am) in fruits and seed 
Table 3. Local alignment results obtained from BLAST of Sonchus arvensis MN206020

\begin{tabular}{|c|c|c|c|c|c|}
\hline Species & Max score & Total score & Query cover & E-value & Per. ident. \\
\hline Sonchus arvensis JX848427.1 & 800 & 800 & $100 \%$ & 0.0 & $100.00 \%$ \\
\hline Sonchus oleraceus KM360989.1 & 800 & 800 & $100 \%$ & 0.0 & $100.00 \%$ \\
\hline Sonchus oleraceus EU385018.1 & 800 & 800 & $100 \%$ & 0.0 & $100.00 \%$ \\
\hline Sonchus asper MF135322.1 & 800 & 800 & $100 \%$ & 0.0 & $100.00 \%$ \\
\hline Sonchus asper HM850372.1 & 800 & 800 & $100 \%$ & 0.0 & $100.00 \%$ \\
\hline
\end{tabular}

Table 4. Local alignment results obtained from BLAST of Sonchus arvensis MN218598

\begin{tabular}{|c|c|c|c|c|c|}
\hline Species & Max score & Total score & Query cover & E-value & Per. ident. \\
\hline Sonchus arvensis MH265200.1 & 521 & 521 & $100 \%$ & $5 E-144$ & $99.31 \%$ \\
\hline Sonchus arvensis MF770209.1 & 521 & 521 & $100 \%$ & $5 \mathrm{E}-144$ & $99.31 \%$ \\
\hline Sonchus arvensis MG225099.1 & 521 & 521 & $100 \%$ & $5 \mathrm{E}-144$ & $99.31 \%$ \\
\hline Sonchus arvensis MG225031.1 & 521 & 521 & $100 \%$ & $5 \mathrm{E}-144$ & $99.31 \%$ \\
\hline Sonchus arvensis MG225020.1 & 521 & 521 & $100 \%$ & $5 \mathrm{E}-144$ & $99.31 \%$ \\
\hline
\end{tabular}

Table 5. Genetic variation in 288 bp of partial maturase K (matK) gene of Sonchus arvensis species. Position based on the sequence of the first sequence obtained from Sonchus arvensis MN218598

\begin{tabular}{|c|c|c|c|}
\hline \multirow[t]{2}{*}{ Species } & \multirow[t]{2}{*}{$\begin{array}{c}\text { Identity } \\
(\%)^{*}\end{array}$} & \multicolumn{2}{|c|}{$\begin{array}{c}\text { Nucleotide } \\
\text { differences at } \\
\text { position }\end{array}$} \\
\hline & & 32 & 33 \\
\hline Sonchus arvensis MN218598 & $100 \%$ & $\mathrm{~A}$ & $\mathrm{C}$ \\
\hline Sonchus arvensis MH265200.1 & $99.31 \%$ & $\mathrm{~T}$ & $\mathrm{~T}$ \\
\hline Sonchus arvensis MF770209.1 & $99.31 \%$ & $\mathrm{~T}$ & $\mathrm{~T}$ \\
\hline Sonchus arvensis MG225099.1 & $99.31 \%$ & $\mathrm{~T}$ & $\mathrm{~T}$ \\
\hline Sonchus arvensis MG225031.1 & $99.31 \%$ & $\mathrm{~T}$ & $\mathrm{~T}$ \\
\hline Sonchus arvensis MG225020.1 & $99.31 \%$ & $\mathrm{~T}$ & $\mathrm{~T}$ \\
\hline
\end{tabular}

Presenting the different view, matK has a high evolutionary rate, compatible length, and noticeable interspecific divergence as well as a low transition/ transversion rate (Min and Hickey 2007). As seen in Table 5 that transversions take place at position nucleotide 32 and transitioning at position nucleotide 33 . Thus, it can affect the circumstances of amino acid from Phenylalanine to Tyrosine.

Phylogenetic analysis reveals a little deviation in the $r b c L$ tree could be as a result of the symmetry in $r b c L$ among a sequence of Sonchus genera (Figure 4). In other words, no difference between the intraspecies and interspecies alteration was noticed in the present study. Dissimilar results shown by MatK tree which $S$. arvensis MN218598 was disjoined from cluster $S$. arvensis acquired from database NCBI with branch length 0.0035 (Figure 5). Gynura japonica (KX527000.1) is placed to outgroup in $r b c L$ tree as those are out of Sonchus genera but still within an Asteraceae family. Whereas, S. oleraceus (EU385397.1) is positioned as outgroup in $m a t K$ tree since the following members are intraspecific of $S$. arvensis.

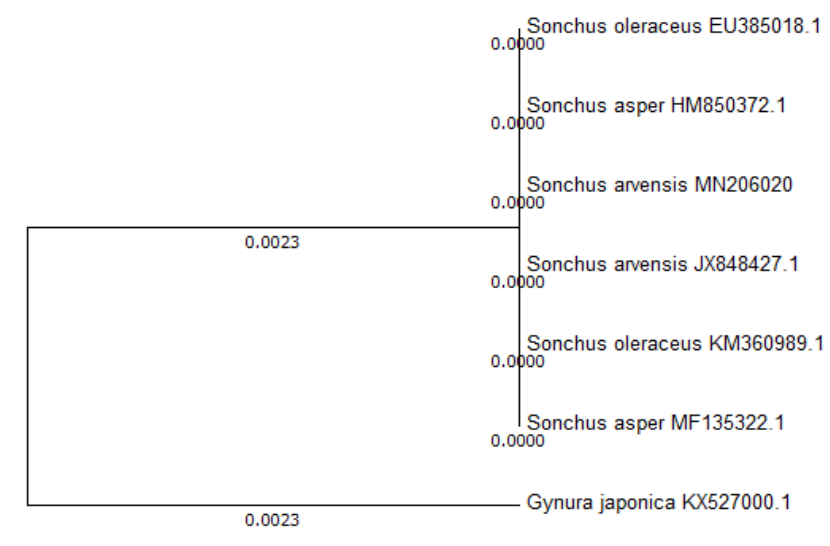

$\begin{array}{lrrrr}1 & 1 & 1 & 1 & 1 \\ 0.00200 & 0.00150 & 0.00100 & 0.00050 & 0.00000\end{array}$

Figure 4. Phylogenetic tree of partial ribulose-1,5-bisphosphate carboxylase/oxygenase large subunit $(r b c L)$ sequence 433bp of 5 species of Sonchus. Gynura japonica (KX527000.1) as outgroup

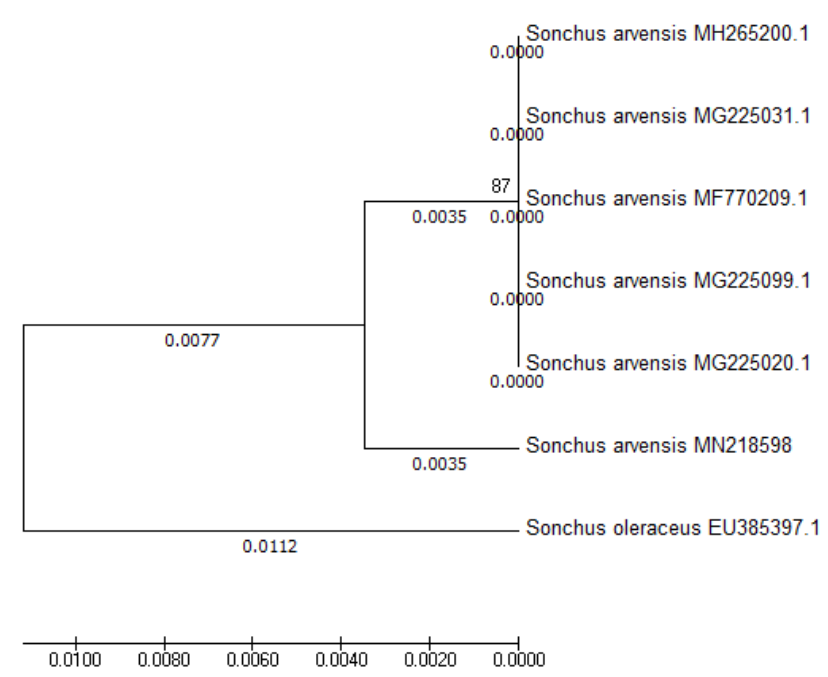

Figure 5. Phylogenetic tree of partial maturase $\mathrm{K}$ (matK) sequence 288bp of 7 species of Sonchus. Sonchus oleraceus (EU385397.1) as outgroup 
Total cpDNA size of Sonchus sp has range 152.071 to 152.194 bp (Cho et al. 2019) with 1428 bp of rbcL gene (Kim et al. 2019) and 1530 bp of matK gene (Kim et al. 2007). Refer to Kim et al. (2007) and Mejías et al. (2018) that Sonchus brachyurous and S. arvensis are closely related base on matK region and put them together into a single clade. This study presents a new phylogenetic analysis of $S$. arvensis using $r b c L$ barcode since numerous deposited sequence in Genbank are unpublished.

Another barcode that employed for DNA barcoding Sonchus sp is ITS (Mejías et al. 2018; (Kim et al. 2007). The ITS spacer is a robust phylogenetic marker at the species level indicating high levels of interspecific separation (Alvarez and Wendel 2003). The higher inequitable power of ITS over plastid regions at low taxonomic levels has been extensively considered leading to it also being recommended as a plant barcode (Stoeckle 2003; Kress et al. 2005; Sass et al. 2007).

Study of morpho-anatomy and DNA barcode have contributed to expanding the information about S. arvensis. Morpho-anatomy of $S$. arvensis has been describing. It was shown that the root, leaves, stem, flower, fruit and seed present morpho-anatomical characteristics that are useful in the identification and differentiation from other species of this genus and are also essential parameters for the quality control of vegetable raw material. For supporting the morpho-anatomical study, the DNA barcode, $r b c L$ and $m a t K$, are also potential to rely on two barcode loci for identification $S$. arvensis.

\section{ACKNOWLEDGMENTS}

The authors would like to thank Plant Medicinal Garden "Taman Husada Graha Family" Surabaya, East Java, Indonesia for the support this work.

\section{REFERENCES}

Alvarez I, Wendel JF. 2003. Ribosomal ITS sequences and plant phylogenetic inference. Mol Phylogenet Evol 29: 417-434

Chase MW, Cowan RS, Hollingsworth PM, Van den Berg C, Madrinan S, Petersen G, Seberg O, Jorgsensen T, Cameron KM, Carine M, Pedersen N, Hedderson TAJ, Conrad F, Salazar GA, Richardson JE, Hollingsworth, ML, Barraclough TG, Kelly L, Wilkinson M. 2007. A proposal for a standardized protocol to barcode all land plants. Taxon 56: 295-299.

Chauhan BS, Widderick M, Cook T. 2015. Common Sowthistle (Sonchus oleraceus L.): Ecology and Management. Northern IWM Factsheet. Department of Agriculture and Fisheries. Queensland.

Cho MS, Yang JY, Yang TJ, Kim SC. 2019. Evolutionary Comparison of the Chloroplast Genome in the Woody Sonchus Alliance (Asteraceae) in the Canary Islands. Genes 10 (3): 217.

Delyan E. 2016. Analysis of the composition of volatile compounds of field sow thistle (Sonchus arvensis L.) leaves using the method of gas chromatography with mass-detection. Pharm Innov 5: 118-121.

Dick CW, Kress WJ. 2009. Dissecting tropical plant diversity with forest plots and a molecular toolkit. Bioscience 59: 745-755

Doğan NY, Kurt P, Osma E. 2018. Determination of genetic diversity of Sonchus erzincanicus Matthews (Asteraceae), a Critically Endangered plant endemic to Turkey using RAPD markers. Biharean Biol 12 (2): 61-64.

Ekasari W, Indah ST, Tutik SW, Aty W, Afraz. 2014. Aktivitas antimalarial fraksi etil asetat daun johar (Cassia siamea Lamk.) terhadap pertumbuhan Plasmodium falcifarum strain G2300 (resisten klorokuin) in vitro. E-Journal Planta Husada 2 (1): 16-19. [Indonesian]

Elkamali HH, El-Kheir MSM, Habeballa RS, Hamaza NB, Abdalla IE, Ahmedani EI, Mohammed AAS, Abuzaid BAA, Mohammed MB, Ahmed TY. 2011. Genetic Relationships of two Sonchus Species Collected from two Locations in Khartoum State Using RAPD Markers. Curr Res J Biol Sci 3 (2): 95-99.

Hollingsworth PM, Forrest LL, Spouge JL, Hajibabaei M, Ratnasingham S, van der Bank M, Chase MW, Cowan RS, Erickson DL, Fazekas AJ, Graham SW, James KE, Kim K-J, John Kress W, Schneider H, van AlphenStahl J, Barrett SCH, van den Berg C, Bogarin D, Burgess KS, Cameron KM, Carine M, Chacón J, Clark A, Clarkson JJ, Conrad F, Devey DS, Ford CS, Hedderson TAJ, Hollingsworth ML, Husband BC, Kelly LJ, Kesanakurti PR, Kim JS, Kim YD, Lahaye R, Lee HL, Long DG, Madriñán S, Maurin O, Meusnier I, Newmaster SG, Park CW, Percy DM, Petersen G, Richardson JE, Salazar GA, Savolainen V, Seberg O, Wilkinson MJ, Yi DK, Little DP. 2009. A DNA barcode for land plants., Proc Natl Acad Sci USA 106 (31): 12794-12797. DOI: 10.1073/pnas.0905845106

Hall TA. 1999. Bio edit: A user-friendly biological sequence alignment editor and analysis program for windows 95/98/NT. Nucl Acids Symp Ser 41: 95-98.

Hebert PDN, Cywinska NA, Ball SL, De Waard JR. 2003. Biological identifications through DNA barcodes. Proc Roy Soc B Biol Sci 270: 313-321.

Hollingsworth PM, Graham SW, Little DP. 2011. Choosing and using a plant DNA barcode. PloS ONE 6: e19254. DOI: 10.1371/journal.pone.0019254.

Kandemir A, Makbul S, Turkmen Z, Yilmaz M. 2006. Morphological, anatomical and palynogical investigation on Sonchus erzincanicus Matthews (Asteraceae). Turk J Bot 30: 405-411.

Kim S-C, Lee C, Mejías JA 2007 Phylogenetic analysis of chloroplast DNA matK gene and ITS of nrDNA sequences reveals polyphyly of the genus Sonchus and new relationships among the subtribe Sonchinae (Asteraceae: Cichorieae). Mol Phylogenet Evol 44: 578597. DOI: 10.1016/j.ympev.2007.03.014

Kim SH, Mejías JA, Kim SC. 2019. Next-generation sequencing reveals the complete plastome sequence of newly discovered cliff-dwelling Sonchus boulosii (Asteraceae: Cichorieae) in Morocco. Mitochondrial DNA Part B 4 (1): 164-165.

Kress WJ, Wurdack KJ, Zimmer EA, Weigt LA, Janzen DH (2005) Use of DNA barcodes to identify flowering plants. Proceedings of the National Academy of Sciences of the United States of America. 2005 May 31. 102: 8369-8374.

Kress WJ, Erickson DL. 2007. A two-locus global DNA barcode for land plants: the coding $r b c L$ gene complements the non-coding trnH-psbA spacer region. PLoS ONE 2: e508. DOI: 10.1371/journal.pone.0000508.

Lahaye R, Van der Bank M, Bogarin D, Warner J, Pupulin F, Gigot G, Maurin O, Duthoit S, Barraclough TG, Savolainen V. 2008. DNA barcoding the floras of biodiversity hotspots. Proc Nat Acad Sci USA 105 (8): 2923-2928.

Lucas C, Thangaradjou T, Papenbrock J (2012) Development of a DNA Barcoding System for Seagrasses: Successful but Not Simple. PLoS ONE 7 (1): e29987. DOI: 10.1371/journal.pone.0029987.

Mejias JA, Rey MGD, Silva JL. 2012. Variability in prickly sow-thistle (Sonchus asper) from the western Mediterranean region. Bocconea 24: 285-293.

Mejías JA, Chambouleyron M, Kim SH, Infante MD, Kim SC, Léger JF. 2018. Phylogenetic and morphological analysis of a new cliff-dwelling species reveals a remnant ancestral diversity and evolutionary parallelism in Sonchus (Asteraceae). Plant Syst Evol 304: 1023-1040 DOI: 10.1007/s00606-018-1523-2.

Min XJ, Hickey DA. 2007. Assessing the effect of varying sequence length on DNA barcoding of fungi. Mol Ecol Notes 7: 365-373.

Psaroudaki A, Nikoloudakis N, Skaracis G, Katsiotis A. 2015. Genetic structure and population diversity of eleven edible herbs of Eastern Crete. J Biol Res Thessaloniki 22 (1): 7.

Qureshi SJ, Awan AG, Khan MJ, Bano S. 2002. Taxonomic study of the genus Sonchus L. from Pakistan. J Biol Sci 2 (5): 309-314.

Qureshi SJ, Khan MJ, Rashid A. 2008. Diameter, exine thickness, and sculpturing in genera Scrorzonera L., Sonchus L and Tragopogon L. of Asteraceae in Pakistan. Intl J Sci Technol 3 (2): 139-149.

Rozen S, Skaletsky H. 2000. Primer3 on the WWW for General Users and for Biologist Programmers. In: Misener S, Krawetz SA (eds.). 
Bioinformatics Methods and Protocols. Methods in Molecular Biology ${ }^{\mathrm{TM}}$. 132. Humana Press. Totowa, USA.

Sass C, Little DP, Stevenson DW, Specht CD. 2007. DNA barcoding in the Cycadales: testing the potential of proposed barcoding markers for species identification of cycads. PLoS ONE 2: e1154. DOI 10.1371/journal.pone.0001154.

Saxena S, Neerja P, Jain DC, Bhakuni RS. 2003. Antimalarial agent from natural sources. Curr Sci 9: 1314-1329.

Sharma S, Richa, Harsimran. 2017. Phytochemical and anatomical screening of Ecliptca prostrata L. an important medical herb from Chandigarh. J Med Pl Stud 5 (2): 255-258.

Sriningsih, Adji HW, Sumaryono W, Wibowo AE, Caidir, Firdayani, Kusumaningrum S, Kartakusuma P. 2012. Analisa Senyawa Golongan Flavonoid Herba Tempuyung (Sonchus arvensis L.) Research report. Pusat P2 Teknologi Farmasi dan Medika Deputi Bidang TAB BPPT, Jakarta. [Indonesian]

Stoeckle M. 2003. Taxonomy, DNA, and the bar code of life. BioScience 53: 796-797.

Subositi D, Hafsah W, Wisyastuti Y. 2018. Karakteristik morfologi dan mikroskopis untuk autentifikasi tempuyung (Sonchus arvensis L). Proceedings of Seminar Nasional Tumbuhan Obat Indonesia ke 55. Universitas Tidar dan Kelompok Kerja Nasional Tumbuhan Obat Indonesia, Magelang, 17-18 October 2018. [Indonesian]

Subositi D, Mujahid R. 2019. Keanekaragaman genetik tempuyung (Sonchus arvensis L.) berdasarkan marka Inter-Simple Sequence Repeats (ISSR). Biosfera 36 (2): 57-62. [Indonesian]
Sukandar EY, Safitri D. 2016. Evaluation of the teratogenic effect of tempuyung (Sonchus arvensis) extracts on Wistar Rats. Intl J Pharmacogn Phytochem Res 8 (5): 761-766.

Sulaksana J, Budi S, Dadang IJ. 2004. Tempuyung Budi Daya dan Pemanfaatan Untuk Obat, Swadaya, Jakarta. [Indonesian]

Svitlana Z, Oksana F, Igor O, Rahman IN, Khan W, Ali K. 2018. Palyno morphological study of the genus Sonchus L. (Asteraceae) species of the flora of Ukraine. Intl J. Biosci 12 (4): 132-144.

Tamura K, Nei M, Kumar S. 2004. Prospects for inferring very large phylogenies by using the neighbor-joining method. Proc Natl Acad Sci USA 101: 11030-11035.

Thompson JD, Higgins DG, Gibson TJ. 1994. Improving the sensitivity of progressive multiple sequence alignment through sequence weighting, position-specific gap penalties and weight matrix choice. Nucl Acids Res 22: 4673-4680.

Weathers JP, Towler M, Hassanali A, Lutgen P, Engeu PO. 2014. Driedleaf Artemisia annua: A practical malaria therapeutic for developing countries. World J Pharmacol 3 (4): 39-55.

Li X, Yang Y, Henry RJ, Rossetto M, Wang Y, Chen S. 2004. Plant DNA barcoding: from gene to genome. Biol Rev.. DOI: 10.1111/brv.12104

Xue CY, Li DZ. 2011. Use of DNA barcode sensu lato to identify traditional Tibetan medicinal plant Gentianopsis paludosa (Gentianaceae). J Syst Evol 49 (3): 267-270. 